tenschappelijk onderzoek, maar eerder van sociaal-wetenschappelijk onderzoek. In Nederland wordt bij dergelijk onderzoek in de regel door de METC's op grond van de WMO geen ethische toetsing uitgevoerd.

Daarom heeft de NVMO recent een commissie ingesteld voor een landelijke ethische toetsingsprocedure voor onderwijsonderzoek. Deze commissie, de NVMO-Ethical Review Board (NVMO-ERB) bestaat uit:

- Prof. dr. J.J.M. van Delden (UMC Utrecht), voorzitter

- Drs. J.I. Dankerlui-Eikelboom (UMC Utrecht), secretaris

- Th. J. ten Cate (UMC Utrecht)

- Dr. A.D.C. Jaarsma (Faculteit Diergeneeskunde - UU)

- Drs. A.N. Raat (UMC Groningen)

- Dr. J. Schönrock-Adema (UMC Groningen)

- Dr. R.L. Hulsman (AMC Amsterdam)

- Dr. W. de Grave (UMC Maastricht)

- Mr. S.K. Kwee, jurist

- Anne Schoutens (student-lid, UMC Utrecht)

Sinds 16 juli 2010 kunnen de leden van de NVMO via de website van de NVMO ( $w w w$. nvmo.nl), onder het kopje 'Ethische toetsing onderwijsonderzoek' hun onderzoek aan een ethische toetsing onderwerpen. Via een link onderaan de pagina volgt er een vragenformulier.

Aan de hand van de antwoorden volgt uiteindelijk een ethisch commentaar. Alle overige informatie is op de site zelf te vinden.

\section{Gereduceerd tarief lidmaatschap IAMSE}

Leden van de NVMO kunnen tegen een gereduceerd tarief lid worden van IAMSE, de International Association of Medical Science Educators. Deze vereniging stelt zich tot doel het medisch onderwijs te verbeteren door middel van docentprofessionalisering en door ervoor te zorgen dat de wetenschappelijke aspecten binnen de medische opleiding behouden blijven. Ze doet dit door onderling onderwijsmaterialen, methoden en ervaringen uit te wisselen en voor elkaar een internationaal multidisciplinair forum te zijn.

Leden van IAMSE hebben direct toegang tot de laatste informatie via de IAMSE discussielijst, kunnen voordelig gebruik maken van activiteiten zoals de Web Audio Seminars en het jaarlijkse congres, en krijgen volledige toegang tot het peer reviewed online tijdschrift Medical Science Educator. Het tijdschrift komt 4 tot 6 maal per jaar uit en richt zich onder andere op ontwikkelingen in de basisopleiding, de klinische training en op het gebied van onderwijsmodellen en onderwijstechnologie.

Als NVMO lid kunt u voor $\$ 99$ per jaar (momenteel ca 70 euro) lid worden van IAMSE (normaal \$ 125). Het lidmaatschap biedt $\mathrm{u}$ een uitgesproken mogelijkheid om uw eigen ontwikkelingen in een internationaal kader te plaatsen en te bediscussiëren. Aanmelden kan via de website www.iamse. org. Voor meer informatie kunt u ook terecht bij Peter de Jong (LUMC, p.g.m.de_ jong@lumc.nl).

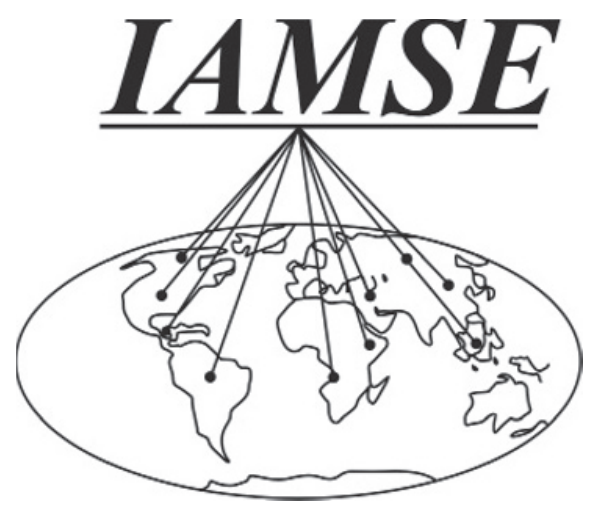

